\title{
Antimicrobial resistance genes in pathogenic Escherichia coli isolated from diseased broiler chickens in Egypt and their relationship with the phenotypic resistance characteristics
}

\author{
Mohamed M. Amer ${ }^{1}$, Hoda M. Mekky², Aziza M. Amer ${ }^{3}$ and Hanaa S. Fedawy ${ }^{2}$
}

1. Department of Poultry Diseases, Faculty Veterinary Medicine, Cairo University, P.O. 12211, Giza, Egypt; 2. Department of Poultry Diseases, Veterinary Research Division, National Research Centre, P.O. 12622, Giza, Egypt; 3. Department of Pharmacology, Faculty Veterinary Medicine, Cairo University, P.O. 12211, Giza, Egypt.

Corresponding author: Mohamed M. Amer, e-mail: profdramer@yahoo.com

Co-authors: HMM: hodamekky@yahoo.com, AMA: aziza.mahrous@gmail.com, HSF: hanaafedawy@yahoo.com

Received: 04-05-2018, Accepted: 29-06-2018, Published online: 09-08-2018

doi: 10.14202/vetworld.2018.1082-1088. How to cite this article: Amer MM, Mekky HM, Amer AM, Fedawy HS (2018) Antimicrobial resistance genes in pathogenic Escherichia coli isolated from diseased broiler chickens in Egypt and their relationship with the phenotypic resistance characteristics, Veterinary World, 11(8): 1082-1088.

\begin{abstract}
Aim: The aim of this study was to determine the relationship between phenotypic resistance and genotypic resistance of isolated serotyped pathogenic Escherichia coli isolates from the clinically diseased broiler.

Materials and Methods: A total of 160 samples (heart, liver, kidney, and lung) were collected from 18 to 34 days old clinically diseased broiler from 40 broiler farms (3-5 birds/farm) reared in Giza and Kaluobaia Governorates for the isolation of pathogenic E. coli. Various E. coli isolates were tested for the pathogenicity based on Congo red (CR) dye binding assay. The obtained CR-positive E. coli isolates were subjected to serological identification using slide agglutination test. Disc diffusion test was used to study the sensitivity pattern of $E$. coli isolates to available 12 antibiotics. Polymerase chain reaction was performed for the detection of antimicrobial resistance genes in the studied pathogenic E. coli isolates.
\end{abstract}

Results: The results revealed that 56 samples $(35 \%)$ were positive for $E$. coli. The results of the CR assay indicates that 20 isolates of $56(35.7 \%)$ were positive and 36 isolates $(64.3 \%)$ were negative. Identified $E$. coli serotypes of CR-positive isolates were 1 (O24), 2 (O44), 2 (O55), 5 (O78), 2 (O86), 1 (124), 3 (O127), 1 (O158), and 3 untyped. Resistance rate in disc diffusion test was $85 \%$ to oxytetracycline and kanamycin; $80 \%$ to ampicillin (AMP), clindamycin, and streptomycin (S); $75 \%$ to enrofloxacin; $65 \%$ to chloramphenicol; $55 \%$ to cefotaxime and gentamicin $(\mathrm{CN}) ; 45 \%$ to trimethoprim+sulfamethoxazole; $35 \%$ to erythromycin (ERI); and 30\% to oxacillin. All strains are multidrug-resistant (MDR). Antibacterial resistance genes CITM, ere, aac (3)-(IV), tet(A), tet(B), dfr(A1), and aad(A1) were detected in $14(70 \%), 12(60 \%), 12(60 \%), 8(40 \%)$, $11(55 \%), 8(40 \%)$, and $9(45 \%)$ of tested 20 isolates, respectively. Multidrug resistance was detected in the form of resistance to $42 \%-83.3 \%$ of tested 12 antibiotics. Three isolates (15\%) of 20 tested isolates showed a relationship between phenotype and genotype and $17(85 \%)$ showed irregular relation. Strains are sensitive and show resistant gene (P-G+) presented in three isolates for AMP (beta-lactam), one for ERI (Macrolide), as well as five isolates for trimethoprim (pyrimidine inhibitor). E. coli isolates had resistance and lacked gene (P+ G-) reported meanly in one isolate for CN (aminoglycoside), two isolates for tetracycline, four isolates for ERI, seven isolates for trimethoprim, and eight isolates for S (aminoglycoside).

Conclusion: The study demonstrates that E. coli is still a major pathogen responsible for disease conditions in broiler. $E$. coli isolates are pathogenic and MDR. Responsible gene was detected for six antibiotics in most of the isolates, but some do not show gene expression, this may be due to few numbers of resistance genes tested or other resistance factors not included in this study.

Keywords: antibiotic resistance genes, broiler, Escherichia coli, isolation.

\section{Introduction}

Escherichia coli are responsible for avian colibacillosis, acute and largely systemic disease that promotes significant economic losses in poultry industry worldwide because of mortality increase, medication costs, and condemnation of carcass [1]. Several reports are available on the involvement

\footnotetext{
Copyright: Amer, et al. Open Access. This article is distributed under the terms of the Creative Commons Attribution 4.0 International License (http://creativecommons.org/licenses/by/4.0/), which permits unrestricted use, distribution, and reproduction in any medium, provided you give appropriate credit to the original author(s) and the source, provide a link to the Creative Commons license, and indicate if changes were made. The Creative Commons Public Domain Dedication waiver (http://creativecommons.org/ publicdomain/zero/1.0/) applies to the data made available in this article, unless otherwise stated.
}

of serotypes of $E$. coli in poultry diseases [2]. The pathogenic and non-pathogenic $E$. coli strains in poultry are differentiated based on the virulence which has been attributed to various factors including fimbriae, production of colicin, motility, and embryo lethality. Hence, detection of these strains become important for effective treatment and control [3].

Resistant to multiple antimicrobials is called multidrug-resistant (MDR) or sometimes superbugs [4]. Many suggestions about the transfer of resistance genes between bacterial generations may be inherent or acquired through vertical or horizontal transfer (transformation, conjugation, and transduction) mechanisms. The development of antibiotic resistance is usually associated with genetic changes encoded by chromosomal and plasmid genes 
harbored by bacterial organisms [5]. Genetic changes either to the acquisition of resistance genes or the mutations in elements relevant for the activity of the antibiotic in bacteria. It was found that, in some situations, resistance can be achieved without any genetic alteration; this is called phenotypic resistance. Non-inherited resistance is associated with specific processes such as a stationary growth phase, growth in biofilms, or persistence [6]. Phenotypic resistance is determined by the genotype [7]. Understanding of the movement of antimicrobial-resistant organisms or resistance genes into food animal life stock and further into people from the food chain and the role of the global food systems in the dissemination of resistance as well as suggested approach for antimicrobial resistance surveillance were discussed [8].

Food animals and their production environments are source and reservoirs of both resistant bacteria and resistance genes that could be transferred to humans either by direct contact with animals or indirectly through the food production chain $[9,10]$ or as a result use of animal wastes in agriculture as a fertilizer [11,12]. E. coli bacteria often carry multiple drug resistance plasmids and, under stress, readily transfer those plasmids to other species. Mixing of species in the intestines allows $E$. coli to accept and transfer plasmids from one to other bacteria, and this process called horizontal gene transfer [13].

Many authors had clarified a lot about the antibiotic resistance profile of bacteria including E. coli in poultry farms in Egypt [14-17] but not much focused on the relationship between phenotypic resistance and genotypic resistance. Therefore, the aim of this study was to determine the relationship between phenotypic resistance and genotypic resistance of isolated serotyped pathogenic $E$. coli isolates from the clinically diseased broiler.

\section{Materials and Methods}

\section{Ethical approval}

This study was approved by the Institutional Animal Ethics Committee and in accordance with local laws and regulations.

\section{Sample collection}

Samples were collected in winter from December 2016 to February 2017. A total of 160 samples (heart, liver, kidney, and lung) were collected from 18 to 34 days old sacrificed clinically diseased broiler from 40 broiler farms (3-5 birds/farm) reared in Giza and Kaluobaia Governorates, Egypt, in separate zipper-lock bag, kept in ice box, and immediately transported to the laboratory. Dead chickens showed lesions of colibacillosis or chronic respiratory disease.

\section{E. coli isolation}

A loopful from each organ were inoculated onto the nutrient broth and incubated aerobically at $37^{\circ} \mathrm{C}$ for $12 \mathrm{~h}$. Loopfuls from incubated nutrient broth were streaked onto Eosin methylene blue (EMB) agar plates and incubated for $24 \mathrm{~h}$ at $37^{\circ} \mathrm{C}$. The suspected colony was picked up and streaked on the MacConkey's agar plates and then incubated for another $24-48 \mathrm{~h}$ at $37^{\circ} \mathrm{C}$. The suspected lactose-fermented colonies were picked up and kept in semi-solid agar for morphological and biochemical identification $[18,19]$.

\section{In vitro pathogenicity testing}

Various serotypes were tested for the pathogenicity based on Congo red (CR) dye binding assay according to Berkhoff and Vinal [20]. Each isolate was cultured on a separate plate of Trypticase soy agar supplemented with $0.003 \%$ CR dye (Sigma) and $0.15 \%$ bile salts. The appearance of deep brick red colonies after incubated at $37^{\circ} \mathrm{C}$ for $24 \mathrm{~h}$ was recorded as positive.

\section{Serological typing of $E$. coli}

The obtained $20 \mathrm{CR}$-positive E. coli isolates were subjected to serological identification [21] using slide agglutination test using polyvalent and monovalent diagnostic E. coli antisera.

\section{Antibacterial susceptibility test}

E.coli isolates were subjected to disc diffusion test to study their sensitivity pattern to available antibiotics. Twelve tested antibacterial agents and their corresponding concentrations were demonstrated as follows: Chloramphenicol $30 \mu \mathrm{g} /$ disk (C30), gentamicin $10 \mu \mathrm{g} /$ disk $(\mathrm{CN})$, erythromycin $15 \mu \mathrm{g} /$ disk (ERI), cefotaxime $30 \mu \mathrm{g} /$ disk (CTX), ampicillin (AMP) $10 \mu \mathrm{g} / \mathrm{disk}$ (A), streptomycin $10 \mu \mathrm{g} /$ disk (S), enrofloxacin (ENR) $5 \mu \mathrm{g} /$ disk, oxytetracycline $30 \mu \mathrm{g} / \mathrm{ml}$ (T30), oxacillin $30 \mu \mathrm{g} / \mathrm{ml}(\mathrm{OX})$, kanamycin $30 \mu \mathrm{g} /$ disk (K), trimethoprim+sulfamethoxazole 2.25/23.75 $\mu \mathrm{g}$ /disk (SXT), and clindamycin $2 \mu \mathrm{g} /$ disk (DA). The plates were inoculated with $E$. coli suspension adjusted to $1.5 \times 10^{8}$ $\mathrm{CFU} / \mathrm{ml}$ corresponding to tube no. $0.5 \mathrm{McF}$ arland standard. The inoculated plates were incubated aerobically at $37 \mathrm{C}$ for $18-24 \mathrm{~h}$, the susceptibility of the $E$. coli isolates to each antimicrobial agent was measured, and the results were interpreted according to CLSI [22]. Resistant to multiple antimicrobials was considered as MDR.

\section{Polymerase chain reaction (PCR)}

Four colonies of each of the tested MDR E. coli isolates were individually subcultured overnight in Luria-Bertani broth (Merck, Germany), and genomic DNA was extracted using a Genomic DNA purification kit (Fermentas, Germany) according to the manufacturer's instructions. PCR amplification and antimicrobial resistance genes were performed according to Peirano et al. [23]. The lysates were used as template in PCR to detect CITM in AMP-resistant isolates, ere in ERI-resistant isolates, aac (3)-(IV) in gentamicin-resistant isolates, $\operatorname{tet}(A)$ and $\operatorname{tet}(B)$ in tetracycline (TC)-resistant isolates, $d f r(A 1)$ in trimethoprim-resistant isolates, and $\operatorname{aad}(A 1)$ in S-resistant isolates (Table-1) [24-26]. Positive controls were 
Table-1: PCR primers, amplicons size, and temperature conditions used for the detection of antimicrobial resistance genes.

\begin{tabular}{|c|c|c|c|c|c|}
\hline Antimicrobial & $\begin{array}{l}\text { Resistance } \\
\text { gene }\end{array}$ & Primers sequence & $\begin{array}{l}\text { Amplicon } \\
\text { size (bp) }\end{array}$ & $\begin{array}{l}\text { Annealing } \\
\text { temperature }\end{array}$ & References \\
\hline \multirow[t]{2}{*}{ AMP } & CITM & F: TGGCCAGAACTGACAGGCAAA & 462 & 47 & {$[24]$} \\
\hline & & R: TTTCTCCTGAACGTGGCTGGC & & & \\
\hline \multirow[t]{2}{*}{ ERI } & ere & F: GCCGGTGCTCATGAACTTGAG & 419 & 52 & [24] \\
\hline & & R: CGACTCTATTCGATCAGAGGC & & & \\
\hline \multirow[t]{2}{*}{ Gentamicin } & $\operatorname{aac}(3)-(I V)$ & F: CTTCAGGATGGCAAGTTGGT & 286 & 55 & {$[24]$} \\
\hline & & R: TCATCTCGTTCTCCGCTCAT & & & \\
\hline \multirow[t]{4}{*}{ Tetracycline } & tet $(A)$ & F: GGTTCACTCGAACGACGTCA & 577 & 57 & {$[25]$} \\
\hline & & R: CTGTCCGACAAGTTGCATGA & & & \\
\hline & tet $(\mathrm{B})$ & F: CCTCAGCTTCTCAACGCGTG & 634 & 56 & \\
\hline & & R: GCACCTTGCTGATGACTCTT & & & \\
\hline \multirow[t]{2}{*}{ Trimethoprim } & $d f r(\mathrm{~A} 1)$ & F: GGAGTGCCAAAGGTGAACAGC & 367 & 45 & {$[26]$} \\
\hline & & R: GAGGCGAAGTCTTGGGTAAAAAC & & & \\
\hline \multirow[t]{2}{*}{ S } & aad $(\mathrm{A} 1)$ & F: TATCCAGCTAAGCGCGAACT & 447 & 58 & {$[25]$} \\
\hline & & R: ATTTGCCGACTACCTTGGTC & & & \\
\hline
\end{tabular}

$\mathrm{PCR}=$ Polymerase chain reaction, $\mathrm{AMP}=$ Ampicillin, $\mathrm{S}=$ Streptomycin, $\mathrm{ERI}=$ Erythromycin

field samples previously confirmed positive (for the related genes) in our biotechnology laboratory, while negative controls were PCR mixture in addition to sterile distilled water.

\section{Results and Discussion}

E. coli infections in birds cause many clinical manifestations which are characterized by a respiratory disease that is frequently followed by a generalized infection which ends by death [1]. Sampled chickens from diseased flocks show postmortem lesions including general congestion, with characteristic fibrinous lesions (airsacculitis, perihepatitis, and pericarditis) and fatal septicemia $[1,27]$.

The results of $E$. coli isolation and identification from diseased field samples revealed that 56 samples $(35 \%)$ were positive. Similar isolation rate was detected [16,28-30]. El Gaber and El-Gohary [31] recovered $E$. coli from $59 \%$ of 150 septicemic broilers, aged 25 days.

The results of the CR-binding assay indicate that 20 isolates of $56(35.7 \%)$ were positive and 36 isolates $(64.3 \%)$ were negative. The results of in vitro pathogenicity testing were in agreement with Berkhoff and Vinal [20], who reported a strong correlation between expression of CR phenotype and virulence in avian E. coli. Pathogenic E. coli can be identified by their ability to bind $\mathrm{CR}$ and produce brick red colonies $[32,33]$. A similar result of $28.6 \%$ of virulent avian E. coli isolates was CR positive [16]. The characteristic of CR binding constitutes a moderately stable, reproducible, and easily distinguishable phenotypic marker. Nevertheless, Yoder [34] has reported that CR binding did not correlate well with pathogenicity.

The most predominant serotypes were $1(\mathrm{O} 24), 2$ (O44), 2 (O55), 5 (O78), 2 (O86), 1 (124), 3 (O127), 1 (O158), and 3 untyped (Table-2). A wide variety of $E$. coli serotypes and non-subtypes from broiler in Egypt were also reported [14-17,35,36].

Isolate resistance rate was $85 \%$ to oxytetracycline and $\mathrm{K} ; 80 \%$ to AMP, DA, and S; $75 \%$ to ENR; $65 \%$
Table-2: Serotypes and percentages of 20 CR-positive E. coli isolates.

\begin{tabular}{lc}
\hline E. coli serotype & Number of isolate (\%) \\
\hline O24 & $1(5)$ \\
O44 & $2(10)$ \\
O55 & $2(10)$ \\
078 & $5(25)$ \\
O86 & $2(10)$ \\
0124 & $1(5)$ \\
O127 & $3(15)$ \\
O158 & $1(5)$ \\
un-typed & $3(15)$ \\
\hline
\end{tabular}

E. coli=Escherichia coli, $\mathrm{CR}=$ Congo red

to $\mathrm{C} ; 55 \%$ to CTX and $\mathrm{CN} ; 45 \%$ to SXT; $35 \%$ to ERI; and $30 \%$ to OX (Table-3). Isolates were resistant to 5-10 tested drugs. This result showed that all isolated strains are MDR (Tables-3 and 4). Similar results were reported by Guerra et al. [37]. High resistant to TC and S [38,39], AMP [40-42], and cephalexin [43] was recorded. Lower resistance rate $(25.3 \%)$ was recorded by Ozawa et al.[42].

Multidrug resistance was detected in the form of resistance to 5 (42\%)-10 (83.3\%) of tested 12 antibiotics (Table-3). Similar results were reported $[40,44,45]$. MDR E. coli and other Enterobacteriaceae isolates are characterized by non-susceptibility to at least one agent in three or more antibiotic categories $[45,46]$.

Phenotypic resistances were verified by PCR amplification and could be traced back to the genes. Of the 20 isolates tested for the presence of antibacterial resistance genes, $14(70 \%)$ were positive to CITM, $12(60 \%)$ for ere and aac (3)-(IV) genes, $8(40 \%)$ for tet(A), $11(55 \%)$ for tet(B), $8(40 \%)$ for $d f r(A 1)$, and $9(45 \%)$ for $\operatorname{aad}(A 1)$. The obtained results of antimicrobial resistance genes agree with Guerra et al. [37], and Szmolka et al. [47]. Van et al. [24] detected tet $A$ and tetB genes in E. coli isolated from broiler chickens. Ying et al. [44] found that $97 \%$ of the AMP-resistant mechanism could be explained by the 
Table-3: Antimicrobial sensitivity pattern of tested $E$. coli isolates $(n=20)$.

\begin{tabular}{|c|c|c|c|c|c|c|c|c|c|c|c|c|c|}
\hline \multirow[t]{2}{*}{ Isolate No. } & \multicolumn{12}{|c|}{ Antibacterial agents } & \multirow{2}{*}{$\frac{\text { Drugs resistant }}{\mathrm{n}(\%)}$} \\
\hline & C30 & $\mathbf{C N}$ & CTX & $\mathbf{A}$ & $\mathbf{S}$ & ERI & ENR & T30 & ox & $\mathbf{K}$ & SXT & DA & \\
\hline 1 & $\mathrm{~S}$ & $\mathrm{R}$ & $\mathrm{S}$ & $\mathrm{R}$ & $\mathrm{R}$ & $\mathrm{R}$ & $\mathrm{R}$ & $\mathrm{R}$ & $\mathrm{S}$ & $\mathrm{R}$ & $\mathrm{R}$ & $\mathrm{R}$ & $9(75)$ \\
\hline 2 & $\mathrm{R}$ & $\mathrm{S}$ & $\mathrm{S}$ & $\mathrm{S}$ & $\mathrm{R}$ & $\mathrm{R}$ & $\mathrm{R}$ & $\mathrm{R}$ & I & $\mathrm{R}$ & $\mathrm{S}$ & $\mathrm{R}$ & $7(58)$ \\
\hline 3 & I & $\mathrm{R}$ & $\mathrm{R}$ & $\mathrm{S}$ & I & $\mathrm{R}$ & $\mathrm{R}$ & $\mathrm{R}$ & $\mathrm{R}$ & $\mathrm{R}$ & $\mathrm{R}$ & I & $8(67)$ \\
\hline 4 & $\mathrm{R}$ & $\mathrm{R}$ & $\mathrm{S}$ & $\mathrm{R}$ & $\mathrm{R}$ & I & $\mathrm{R}$ & $\mathrm{R}$ & $\mathrm{S}$ & I & $\mathrm{S}$ & $\mathrm{R}$ & $7(58)$ \\
\hline 5 & $\mathrm{I}$ & $\mathrm{I}$ & $\mathrm{S}$ & $\mathrm{S}$ & $\mathrm{R}$ & $\mathrm{R}$ & $\mathrm{I}$ & $\mathrm{R}$ & $\mathrm{R}$ & $\mathrm{R}$ & $\mathrm{R}$ & $\mathrm{S}$ & $6(50)$ \\
\hline 6 & $\mathrm{R}$ & $\mathrm{R}$ & $\mathrm{S}$ & $\mathrm{R}$ & $\mathrm{R}$ & $\mathrm{R}$ & $\mathrm{R}$ & $\mathrm{R}$ & $\mathrm{S}$ & $\mathrm{R}$ & $\mathrm{R}$ & $\mathrm{R}$ & $10(83.3)$ \\
\hline 7 & $\mathrm{R}$ & $\mathrm{R}$ & $\mathrm{S}$ & $\mathrm{R}$ & $\mathrm{R}$ & $\mathrm{R}$ & $\mathrm{R}$ & $\mathrm{R}$ & $\mathrm{R}$ & $\mathrm{R}$ & $\mathrm{S}$ & $\mathrm{R}$ & $10(83.3)$ \\
\hline 8 & $\mathrm{R}$ & $\mathrm{R}$ & $\mathrm{R}$ & $\mathrm{S}$ & $\mathrm{R}$ & $\mathrm{R}$ & $\mathrm{R}$ & $\mathrm{R}$ & $\mathrm{S}$ & $\mathrm{R}$ & $\mathrm{R}$ & $\mathrm{R}$ & $10(83.3)$ \\
\hline 9 & $\mathrm{I}$ & $\mathrm{I}$ & $\mathrm{S}$ & $\mathrm{R}$ & $\mathrm{R}$ & $\mathrm{R}$ & $\mathrm{R}$ & $\mathrm{R}$ & $\mathrm{S}$ & $\mathrm{R}$ & $\mathrm{R}$ & $\mathrm{I}$ & $7(58)$ \\
\hline 10 & $\mathrm{R}$ & $\mathrm{S}$ & $\mathrm{S}$ & $\mathrm{S}$ & $\mathrm{I}$ & $\mathrm{R}$ & $\mathrm{R}$ & $\mathrm{R}$ & $\mathrm{I}$ & $\mathrm{R}$ & $\mathrm{S}$ & $\mathrm{R}$ & $6(50)$ \\
\hline 11 & I & $\mathrm{S}$ & $\mathrm{S}$ & $\mathrm{R}$ & $\mathrm{R}$ & $\mathrm{S}$ & I & $S$ & $\mathrm{R}$ & $\mathrm{R}$ & $\mathrm{R}$ & $\mathrm{S}$ & $5(42)$ \\
\hline 12 & $\mathrm{R}$ & $\mathrm{R}$ & $\mathrm{R}$ & $\mathrm{S}$ & $\mathrm{R}$ & $\mathrm{R}$ & $\mathrm{R}$ & $\mathrm{R}$ & $\mathrm{S}$ & $\mathrm{R}$ & $\mathrm{R}$ & $\mathrm{R}$ & $10(83.3)$ \\
\hline 13 & $\mathrm{R}$ & $\mathrm{S}$ & $\mathrm{S}$ & $\mathrm{R}$ & $\mathrm{R}$ & $\mathrm{R}$ & $\mathrm{R}$ & $\mathrm{R}$ & I & $\mathrm{R}$ & I & $\mathrm{R}$ & $8(67)$ \\
\hline 14 & $\mathrm{R}$ & $\mathrm{R}$ & $\mathrm{R}$ & $\mathrm{S}$ & $\mathrm{R}$ & $\mathrm{S}$ & $\mathrm{R}$ & I & $\mathrm{S}$ & $\mathrm{S}$ & $\mathrm{S}$ & $\mathrm{R}$ & $6(50)$ \\
\hline 15 & $\mathrm{~S}$ & $\mathrm{~S}$ & $\mathrm{~S}$ & $\mathrm{R}$ & $\mathrm{R}$ & $\mathrm{S}$ & $\mathrm{R}$ & $\mathrm{S}$ & $\mathrm{R}$ & $\mathrm{R}$ & $\mathrm{S}$ & $\mathrm{R}$ & $6(50)$ \\
\hline 16 & $\mathrm{R}$ & $\mathrm{S}$ & $\mathrm{R}$ & $\mathrm{S}$ & $\mathrm{S}$ & $\mathrm{R}$ & I & $\mathrm{R}$ & $\mathrm{S}$ & $\mathrm{R}$ & $\mathrm{S}$ & $\mathrm{R}$ & $6(50)$ \\
\hline 17 & I & $\mathrm{R}$ & $\mathrm{S}$ & $\mathrm{R}$ & $\mathrm{R}$ & $\mathrm{R}$ & $\mathrm{S}$ & $\mathrm{R}$ & $\mathrm{R}$ & $\mathrm{R}$ & $\mathrm{R}$ & $\mathrm{R}$ & $9(75)$ \\
\hline 18 & $\mathrm{R}$ & $\mathrm{R}$ & $\mathrm{R}$ & $\mathrm{R}$ & $\mathrm{S}$ & $\mathrm{R}$ & $\mathrm{R}$ & $\mathrm{R}$ & $\mathrm{S}$ & $\mathrm{S}$ & $\mathrm{S}$ & $\mathrm{R}$ & $8(67)$ \\
\hline 19 & $\mathrm{R}$ & $\mathrm{S}$ & $\mathrm{R}$ & $\mathrm{S}$ & $\mathrm{R}$ & $\mathrm{R}$ & I & $\mathrm{R}$ & $\mathrm{S}$ & $\mathrm{R}$ & $\mathrm{S}$ & $\mathrm{R}$ & $7(58.3)$ \\
\hline 20 & $\mathrm{R}$ & $\mathrm{R}$ & $\mathrm{S}$ & $\mathrm{R}$ & $\mathrm{R}$ & $\mathrm{R}$ & $\mathrm{R}$ & $\mathrm{R}$ & I & $\mathrm{R}$ & I & $\mathrm{R}$ & $9(75)$ \\
\hline Total R & 13 & 11 & 7 & 11 & 16 & 16 & 15 & 17 & 6 & 17 & 9 & 16 & \\
\hline$\%$ & 65 & 55 & 35 & 55 & 80 & 80 & 75 & 85 & 30 & 85 & 45 & 80 & \\
\hline
\end{tabular}

$\mathrm{R}=$ Resistant, $\mathrm{S}=$ Sensitive, I=Intermediate, C30=Chloramphenicol $30 \mu \mathrm{g} / \mathrm{disk}, \mathrm{CN}=$ Gentamicin $10 \mu \mathrm{g} / \mathrm{disk}$, $\mathrm{ERI}=$ Erythromycin $15 \mu \mathrm{g} /$ disk, $\mathrm{CTX}=$ Cefotaxime $30 \mu \mathrm{g} /$ disk, A=Ampicillin $10 \mu \mathrm{g} /$ disk, $\mathrm{S}=$ Streptomycin $10 \mu \mathrm{g} /$ disk, ENR=Enrofloxacin $5 \mu \mathrm{g} /$ disk, T30=Oxytetracycline $30 \mu \mathrm{g} / \mathrm{ml}, \mathrm{OX}=$ Oxacillin $30 \mu \mathrm{g} / \mathrm{ml}, \mathrm{K}=$ Kanamycin $30 \mu \mathrm{g} / \mathrm{disk}$, SXT=Trimethoprim+sulfamethoxazole $2.25 / 23.75 \mu \mathrm{g} / \mathrm{disk}$, DA: Clindamycin $2 \mu \mathrm{g} / \mathrm{disk}$, E. coli=Escherichia coli

Table-4: Phenotype antibiotic resistance of $E$. coli in relation to detected genotype.

\begin{tabular}{|c|c|c|c|c|c|c|c|c|c|c|c|c|c|c|c|}
\hline \multirow[t]{2}{*}{ Isolate No } & \multicolumn{7}{|c|}{ Phenotype } & \multicolumn{8}{|c|}{ Genotype } \\
\hline & $\mathbf{A}$ & ERI & CN & T30 & SXT & $\mathbf{S}$ & $\begin{array}{l}\text { Number of } \\
\text { antibiotic } \\
\text { resistant }\end{array}$ & CITM & ere & $\begin{array}{c}\operatorname{aac}(3) \\
\text { (IV) }\end{array}$ & tet $(A)$ & tet (B) & dfr (A1) & aad (A1) & $\begin{array}{l}\text { Number } \\
\text { of gens }\end{array}$ \\
\hline 1 & $\mathrm{R}$ & $\mathrm{R}$ & $\mathrm{R}$ & $\mathrm{R}$ & $\mathrm{R}$ & $\mathrm{R}$ & 6 & + & + & + & + & - & + & - & 5 \\
\hline 2 & $\mathrm{~S}$ & $\mathrm{R}$ & $\mathrm{s}$ & $\mathrm{R}$ & $\mathrm{S}$ & $\mathrm{R}$ & 3 & - & - & - & + & + & + & + & 4 \\
\hline 3 & $\mathrm{~S}$ & $\mathrm{R}$ & $\mathrm{R}$ & $\mathrm{R}$ & $\mathrm{R}$ & I & 4 & - & - & + & - & + & - & - & 2 \\
\hline 4 & $\mathrm{R}$ & I & $\mathrm{R}$ & $\mathrm{R}$ & $\mathrm{S}$ & $\mathrm{R}$ & 4 & + & - & + & - & + & + & + & 5 \\
\hline 5 & $\mathrm{~S}$ & $\mathrm{R}$ & I & $\mathrm{R}$ & $\mathrm{R}$ & $\mathrm{R}$ & 4 & + & + & + & - & + & - & - & 4 \\
\hline 6 & $\mathrm{R}$ & $\mathrm{R}$ & $\mathrm{R}$ & $\mathrm{R}$ & $\mathrm{R}$ & $\mathrm{R}$ & 6 & + & + & + & - & + & - & - & 4 \\
\hline 7 & $\mathrm{R}$ & $\mathrm{R}$ & $\mathrm{R}$ & $\mathrm{R}$ & $\mathrm{S}$ & $\mathrm{R}$ & 5 & + & + & - & - & + & - & - & 3 \\
\hline 8 & $\mathrm{~S}$ & $\mathrm{R}$ & $\mathrm{R}$ & $\mathrm{R}$ & $\mathrm{R}$ & $\mathrm{R}$ & 5 & - & + & + & - & + & - & - & 3 \\
\hline 9 & $\mathrm{R}$ & $\mathrm{R}$ & I & $\mathrm{R}$ & $\mathrm{R}$ & $\mathrm{R}$ & 5 & + & + & + & + & - & - & - & 4 \\
\hline 10 & $\mathrm{~S}$ & $\mathrm{R}$ & $\mathrm{S}$ & $\mathrm{R}$ & $\mathrm{S}$ & I & 2 & - & - & - & + & - & - & + & 2 \\
\hline 11 & $\mathrm{R}$ & $\mathrm{S}$ & $\mathrm{S}$ & $\mathrm{S}$ & $\mathrm{R}$ & $\mathrm{R}$ & 3 & + & - & - & - & - & + & + & 3 \\
\hline 12 & $\mathrm{~S}$ & $\mathrm{R}$ & $\mathrm{R}$ & $\mathrm{R}$ & $\mathrm{R}$ & $\mathrm{R}$ & 5 & - & + & + & - & + & - & + & 4 \\
\hline 13 & $\mathrm{R}$ & $\mathrm{R}$ & $\mathrm{S}$ & $\mathrm{R}$ & I & $\mathrm{R}$ & 4 & + & + & - & + & - & - & - & 3 \\
\hline 14 & $\mathrm{~S}$ & $\mathrm{~S}$ & $\mathrm{R}$ & I & $\mathrm{S}$ & $\mathrm{R}$ & 2 & - & + & + & - & + & - & + & 4 \\
\hline 15 & $\mathrm{R}$ & $\mathrm{S}$ & $\mathrm{S}$ & $\mathrm{S}$ & $\mathrm{S}$ & $\mathrm{R}$ & 2 & + & - & - & - & + & + & + & 4 \\
\hline 16 & $\mathrm{~S}$ & $\mathrm{R}$ & $\mathrm{S}$ & $\mathrm{R}$ & $\mathrm{S}$ & $\mathrm{S}$ & 2 & + & + & - & - & - & + & - & 3 \\
\hline 17 & $\mathrm{R}$ & $\mathrm{R}$ & $\mathrm{R}$ & $\mathrm{R}$ & $\mathrm{R}$ & $\mathrm{R}$ & 6 & + & - & + & - & - & - & - & 2 \\
\hline 18 & $\mathrm{R}$ & $\mathrm{R}$ & $\mathrm{R}$ & $\mathrm{R}$ & $\mathrm{S}$ & $S$ & 4 & + & + & + & + & - & - & - & 4 \\
\hline 19 & $\mathrm{~S}$ & $\mathrm{R}$ & $\mathrm{S}$ & $\mathrm{R}$ & $\mathrm{S}$ & $\mathrm{R}$ & 3 & + & - & - & + & - & + & + & 4 \\
\hline 20 & $\mathrm{R}$ & $\mathrm{R}$ & $\mathrm{R}$ & $\mathrm{R}$ & I & $\mathrm{R}$ & 5 & + & + & + & + & + & + & + & 7 \\
\hline $\begin{array}{l}\text { Number of } \\
\text { positive }\end{array}$ & 11 & 16 & 11 & 17 & 9 & 16 & & 14 & 12 & 12 & 8 & 11 & 8 & 9 & \\
\hline$\%$ & 55 & 80 & 55 & 85 & 45 & 80 & & 70 & 60 & 60 & 40 & 55 & 40 & 45 & \\
\hline
\end{tabular}

$\mathrm{R}=$ Resistant, $\mathrm{S}=$ Sensitive, $\mathrm{I}=$ Intermediate, $\mathrm{A}=$ Ampicillin $10 \mu \mathrm{g} /$ disk, ERI = Erythromycin $15 \mu \mathrm{g} /$ disk, $\mathrm{CN}=$ Gentamicin $10 \mu \mathrm{g} /$ disk, T30 = Oxytetracycline $30 \mu \mathrm{g} / \mathrm{ml}$, SXT = Trimethoprim + sulfamethoxazole 2.25/23.75 $\mu \mathrm{g} /$ disk, $\mathrm{S}=$ Streptomycin $10 \mu \mathrm{g} /$ disk, CITM = Ampicillin-resistant gen, Ere = Erythromycin-resistant gene, $\operatorname{aac}(3)-(I V)=$ Gentamicin-resistant gene, tet $(A)$ and tet $(B)=$ Tetracycline-resistant genes, dfr $(A 1)=$ Trimethoprim-resistant gene, aad $(A 1)=$ Streptomycin-resistant gene, $E$. coli = Escherichia coli 
resistance gene $T E M ; 90 \%$ of the TC was explained by $\operatorname{tet}(A), \operatorname{tet}(B)$, and tet $(M)$ resistance genes; and $96 \%$ of the SXT resistances could be explained by sul(I), sul(II), and sul(III) resistance genes.

Multiresistance genes $>2$ were detected in 17 isolates $(85 \%)$, of them 12 isolates $(60 \%)$ showed 4-7 resistance genes (Table-4). E. coli had been reported as a contributor to disseminate antibiotic resistance genes in natural environments [48,49]. One TC gene, either $\operatorname{tet}(A)$ or $\operatorname{tet}(B)$, was detected in $75 \%$ of isolates as reported by Henriques et al. [50] whom screening of tet genes by PCR showed that $88 \%$ of the isolates carried at least one of the six tested genes. Three isolates $(15 \%)$ of 20 tested isolates showed a relationship between phenotype and genotype, while 17 (85\%) showed irregular relation (Table-5). This result is agreed with those reported in E. coli and Salmonella isolated from calves showed similar antimicrobial drug resistance patterns and several differences in resistance gene profile [51], and phenotype-genotype mapping is suggested to be complex and includes various mutations that cause similar phenotypic changes in analyses of phenotypic and genotypic changes of antibiotic-resistant E. coli strains [52].

E. coli isolates sensitive and has the resistant gene $(\mathrm{P}-\mathrm{G}+)$ presented in three isolates for AMP (beta-lactam), one for both ERI (macrolide), as well as five isolates for trimethoprim (pyrimidine inhibitor) (Table-5). These strains appeared to harbor pseudogenes, which are defined as inactive but stable components of the genome derived by the mutation of an ancestral active gene [53] and likely to be an underestimate of the true prevalence of pseudogenes in the tested E. coli populations. This represents a serious limitation of an assay dependent on the detection of phenotype-genotype discrepancies with the intent to discover pseudogenes [54,55]. E. coli isolates had resistance and lacked gene $\left(\mathrm{P}+\mathrm{G}^{-}\right)$reported meanly in one isolate for $\mathrm{CN}$ (aminoglycoside), two isolates for TC, four isolates for ERI (macrolide), seven isolates for trimethoprim (pyrimidine inhibitor), and eight isolates for $\mathrm{S}$ (aminoglycoside) (Table 5). These results can be attributed to mutations in the promoter and attenuator sequences of chromosomal genes as reported by Daniels et al. [56], Mulvey et al. [57], and Escudero et al. [58]. All isolates phenotypically resistant to OX did not have the mecA gene [59], and only six of seven phenotypically completely resistant to OX CNS species expressed the mecA gene [60].

\section{Conclusion}

The present study demonstrates the occurrence of pathogenic MDR E. coli in broiler chickens in Egypt. Antibiotics resistance genes were detected in most of the isolates, but some do not show gene expression, this may be due to testing for few numbers of resistance genes or other resistance factors not included in this study.

\section{Authors' Contributions}

MMA designed, planned this study, drafted, and revised the manuscript. HMM, AMA, and HSF shared in samples collection, performing the tests, manuscript writing, and data analysis. All authors read and approved the final manuscript.

\section{Acknowledgments}

The authors thank the members of the Biotechnology Laboratory, Faculty of Veterinary

Table-5: E. coli showing an antibiotic pattern and gene detection $P+\mathrm{G}-($ Yellow), $P-\mathrm{G}+$ (blue), and $P+\mathrm{G}+$ (light green).

\begin{tabular}{|c|c|c|c|c|c|c|c|c|c|c|c|c|c|}
\hline \multirow{2}{*}{$\begin{array}{l}\text { Isolate } \\
\text { No }\end{array}$} & \multicolumn{2}{|c|}{ Ampicillin } & \multicolumn{2}{|c|}{ Gentamycin } & \multicolumn{2}{|c|}{ ERI } & \multicolumn{3}{|c|}{ Tetracycline } & \multicolumn{2}{|c|}{ Trimethoprim } & \multicolumn{2}{|r|}{$\mathbf{S}$} \\
\hline & $\mathbf{A}$ & CITM & $\mathrm{CN}$ & $\operatorname{aac}(3)(I V)$ & ERI & ere & T30 & tet (A) & tet (B) & SXT & dfr (A1) & $\mathbf{S}$ & aad (A1) \\
\hline 1 & & & & & & & & & & & & $\mathrm{R}$ & - \\
\hline 2 & & & & & $\mathrm{R}$ & - & & & & $S$ & + & & \\
\hline 3 & & & & & $R$ & - & & & & $\mathrm{R}$ & - & & \\
\hline 4 & & & & & & & & & & $\mathrm{~S}$ & + & & \\
\hline 5 & $S$ & + & & & & & & & & $\mathrm{R}$ & - & $\mathrm{R}$ & - \\
\hline 6 & & & & & & & & & & $\mathrm{R}$ & - & $\mathrm{R}$ & - \\
\hline 7 & & & $\mathrm{R}$ & - & & & & & & & & $\mathrm{R}$ & - \\
\hline 8 & & & & & & & & & & $\mathrm{R}$ & - & $\mathrm{R}$ & - \\
\hline 9 & & & & & & & & & & $\mathrm{R}$ & - & $\mathrm{R}$ & - \\
\hline 10 & & & & & $\mathrm{R}$ & - & & & & & & & \\
\hline 12 & & & & & & & & & & $\mathrm{R}$ & - & $\mathrm{R}$ & - \\
\hline $\begin{array}{l}13 \\
14\end{array}$ & & & & & $\mathrm{~S}$ & + & & & & & & & \\
\hline 15 & & & & & & & & & & $\mathrm{~S}$ & + & & \\
\hline 16 & $S$ & + & & & & & $\mathrm{R}$ & - & - & $\mathrm{S}$ & + & & \\
\hline 17 & & & & & & & $\mathrm{R}$ & - & - & $\mathrm{R}$ & - & $\mathrm{R}$ & - \\
\hline 19 & $\mathrm{~S}$ & + & & & $\mathrm{R}$ & - & & & & $\mathrm{S}$ & + & & \\
\hline
\end{tabular}

$\mathrm{R}=$ Resistant, $\mathrm{S}=$ Sensitive, $\mathrm{I}=$ Intermediate, $\mathrm{A}=$ Ampicillin $10 \mu \mathrm{g} /$ disk, ERI=Erythromycin $15 \mu \mathrm{g} /$ disk, $\mathrm{CN}=\mathrm{Gentamicin}$ $10 \mu \mathrm{g} /$ disk, T30=Oxytetracycline $30 \mu \mathrm{g} / \mathrm{ml}$, SXT=Trimethoprim+sulfamethoxazole2.25/23.75 $\mu \mathrm{g} /$ disk, S=Streptomycin $10 \mu \mathrm{g} /$ disk. CITM=Ampicillin-resistant gene, ere=Erythromycin-resistant gene, aac (3)-(IV)=Gentamicin-resistant gene, $\operatorname{tet}(A)$ and $\operatorname{tet}(B)=$ Tetracycline-resistant genes, $\operatorname{dfr}(A 1)=$ Trimethoprim-resistant gene, $\operatorname{aad}(A 1)=$ Streptomycin-resistant gene, E. coli=Escherichia coli 
Medicine, Cairo University, who facilitate the application of the PCR technique. The authors declared that they did not have any funding source to support their study.

\section{Competing Interests} interests.

The authors declare that they have no competing

\section{References}

1. Saif, Y.M., Barnes, H.J., Fadly, A.M., Glisson, J.R. and Swayne, D.E. (2003) Colibacillosis. In: Poultry Diseases. $11^{\text {th }}$ ed. Iowa State Press, Iowa.

2. Roy, P., Edwin, P.G. and Purushothaman, V. (2004) Characterization of Escherichia coli isolates from hatchery and breeder hens. Indian Vet. J., 81: 1317-1320.

3. Susantha, M.G., Riddell, C., Andrew, A.P. and Allan, B.J. (2001) Phenotypic and genotypic characterization of virulence factors of Escherichia coli isolated from broiler chickens with simultaneous occurrence of cellulitis and other colibacillosis lesions. Can. J. Vet. Res., 65: 1-6.

4. CDC. (2009) Antibiotic Resistance Questions and Answers. Get Smart: Know When Antibiotics Work. Centers for Disease Control and Prevention, USA. Available from: https://www.cdc.gov/antibiotic-use/community/about/ index.html. Accessed on 30-06-2009.

5. Bennett, P.M. (2008) Review: Plasmid-encoded antibiotic resistance: acquisition and transfer of antibiotic resistance genes in bacteria. Br. J. Pharmacol., 153: S347-S357.

6. Corona, F. and Martinez, L. (2013) Review: Phenotypic resistance to antibiotics. Antibiotics, 2: 237-255.

7. Morrison, B.J. and Rubin, J.E. (2015) Carbapenemase producing bacteria in the food supply escaping detection. PLoS One, 10(5): e0126717.

8. WHO. (2014) Antimicrobial Resistance: Global Report on Surveillance. Geneva: World Health Organization.

9. Marshall, B.M. and Levy, S.B. (2011) Food animals and antimicrobials: Impacts on human health. Clin. Microbiol. Rev., 24: 718-733.

10. WHO. (2011) Tackling Antibiotic Resistance from a Food Safety Perspective in Europe. Available from: http://www. euro.who.int/ data/assets/pdf file/0005/136454/e94889. pdf. Last accessed on 08-03-2018.

11. Heuer, H. and Smalla, K. (2007) Manure and sulfadiazine synergistically increased bacterial antibiotic resistance in soil over at least two months. Environ. Microbiol., 9: 657-666.

12. Gosh, S. and LaPara, T.M. (2007) The effects of subtherapeutic antibiotic use in farm animals on the proliferation and persistence of antibiotic resistance among soil bacteria. ISME J., 1: 191-203.

13. Salyers, A.A., Gupta, A. and Wang, Y. (2004) Human intestinal bacteria as reservoirs for antibiotic resistance genes. Trends Microbiol., 12(9): 412-416.

14. Yousef, S.A., Ammar, A.M. and Ahmed, D.A. (2013) Serological and molecular typing of avian pathogenic E. coli originating from outbreaks of colibacillosis in chicken flocks. Internat. J. Sci. Res., 4(2): 2082-2088.

15. Abd El Tawab, A.A., Ammar, M.A., Nasef, A.S. and Reda, M.R. (2015) Prevalence of E. coli in diseased chickens with its antibiogram pattern. Benha Vet. Med. J., 28(2): 224-230.

16. Amer, M.M., Bastamy, M., Elbayoumi, K.M. and Mervat, S. (2015) Isolation and characterization of avian pathogenic Escherichia coli from broiler chickens in some Governorates of Egypt. Vet. Med. J. Giza (VMJG), 61(1): 1-7.

17. Moawad, A.A., Hotzel, H., Awad, O., Tomaso, H., Neubauer, H., Hafez, H.M. and ElAdawy, H. (2017) Occurrence of Salmonella enterica and $w$ in raw chicken and beef meat in Northern Egypt and dissemination of their antibiotic resistance markers. Gut Pathog., 9: 57.
18. Konemann, E.W., Allen, S.D., Schrechen, W.M., Berrjer, P.C. and Winn, W.J.P. (1992) Colour Atlas and Textbook of Diagnostic Microbiology. $4^{\text {th }}$ ed. J.B. Lippincott Co., Philadelphia, USA.

19. Quinn, P.J., Carter, M.E., Markey, B.K., Donnoly, W.J. and Leonard, F.C. (2002) Veterinary Microbiology and Microbial Diseases 166-1117 Osney Mead. Oxford First Ltd, Registered in the United Kingdom.

20. Berkhoff, H.A. and Vinal, A.C. (1986) Congo red medium to distinguish between invasive and non-invasive Escherichia coli for poultry. Avian Dis., 30: 117-121.

21. Edward, P.R. and Ewing, W.H. (1972): Identification of Enterobacteriaceae. $3^{\text {rd }}$ ed. Burgess Publishing Co., Minneapolis. p709.

22. CLSI. (2013) Performance Standards for Antimicrobial Susceptibility Testing. CLSI Approved Standard. Clinical and Laboratory Standard Institute, Wayne, PA.

23. Peirano, G., Agersø, Y., Aarestrup, F.M., Falavina dos Reis, F.M. and Rodirgues, D.P. (2006) Occurrence of integrons and antimicrobial resistance genes among Salmonella enterica from Brazil. J. Antimicrob. Chemother., 58: 305-309.

24. Van, T.T., Chin, J., Chapman, T., Tran, L.T. and Coloe, P.J. (2008) Safety of raw meat and shellfish in Vietnam: an analysis of Escherichia coli isolations for antibiotic resistance and virulence genes. Internat. J. Food Microbiol., 124: 217-223.

25. Puño-Sarmiento, J., Medeiros, L., Chiconi, C., Martins, F., Pelayo, J., Rocha, S., Blanco, J., Blanco, M., Zanutto, M., Kobayashi, R. and Nakazato, G. (2013) Detection of diarrheagenic Escherichia coli strains isolated from dogs and cats in Brazil. Vet. Microbiol., 166: 676-680.

26. Torkan, S., Khamesipour, F. and Anyanwu, M.U. (2015) Detection of virulence and antibacterial resistance genes in Salmonella isolates from diarrhoeic dogs in Iran. Rev. Méd. Vét., 166: 221-228.

27. Sharada, R., Wilfred, R.S. and Thiyageeswaran, M. (2010) Isolation, characterization and antibiotic resistance pattern of Escherichia coli isolated from poultry. Am. Eur. J. Sci. Res., 5: 18-22.

28. Hussein, A.H., Ghanem, I.A., Eid, A.A., Ali, M.A., Sherwood, J.S., Li, G., Nolan, L.K. and Logue, C.M. (2013) Molecular and phenotypic characterization of Escherichia coli isolated from broiler chicken flocks in Egypt. Avian Dis., 57(3): 602-611.

29. Abd El Tawab, A.A., Maarouf, A.A.A., Abd El Al, S.A., El Hofy, F.I. and El Mougy, E.E.A. (2014) Detection of some virulence genes of avian pathogenic $E$. coli by polymerase chain reaction. Benha Vet. Med. J., 26(2): 159-176.

30. El- sayed, M.E., Shabana, I.I., Esawy, A.M. and Rashed, A.M. (2015) Detection of virulence-associated genes of avian pathogenic Escherichia coli (APEC) isolated from broilers. J. Gen., 1(1): 4.

31. El-Gaber, G.A. and El-Gohary, A.A. (1995) Studies on pyocin typing, dermonecrosis and pathogenicity of Escherichia coli recovered from septicaemic broiler chickens. Vet. Med. J., 43(2): 213-218.

32. Singh, M.P. and Gupta, R.S. (1996) Congo red binding test - A marker for avian pathogenic E. coli strains. Indian $J$. Comp. Microbiol. Immunol. Infect. Dis., 17: 83-84.

33. Abhilasha, S.S.P. and Gupta, R.S. (2001) Pathogenicity and in vitro drug resistance of Escherichia coli isolated from colibacillosis cases in chicks of Tarai Region. Indian $J$. Comp. Microbiol., Immunol. Inf. Dis., 22(2): 166-167.

34. Yoder, H.W. (1989) Congo red binding by Escherichia coli isolates from chickens. Avian Dis., 33: 502-505.

35. Taha, M., Ibrahim, R.S. and Hussien, A.A.A. (2002) Studying the pathogenicity and RAPD PCR analysis of different Escherichia coli serotypes isolated from broilers and layer chickens. Assiut Vet. Med. J., 46(92): 224-236.

36. Salama, S.S., Afaf, A.K., Elham, A.E. and Taha, M.M. (2007) Molecular strategies for the differentiation and identification 
of local Escherichia coli isolated from chicken: I. characterization of protein profile. B. S. Vet. Med. J., 17(1): 25-28.

37. Guerra, B., Junker, E., Schroeter, A., Malorny, B., Lehmann, S. and Helmuth, R. (2003) Phenotypic and genotypic characterization of antimicrobial resistance in German Escherichia coli isolates from cattle, swine and poultry. $J$. Antimicrob. Chemother., 52(3): 489-492.

38. Zhao, S., Maurerb, J.J., Hubert, S., Villena, J.F.D., Dermott, P.F.M., Meng, J., Ayersa, S., English, L. and White, D.G. (2005) Antimicrobial susceptibility and molecular characterization of avian pathogenic Escherichia coli isolates. Vet. Microbiol., 107: 215-224.

39. Gyles, L.C. (2008) Antimicrobial resistance in selected bacteria from poultry. Anim. Health Res. Rev., 9(2): 149-158.

40. Xin-sheng, L., Gui-Qin, W., Xiang-Dang, D., Bao-An, C., Su-Mei, Z. and Jian-Zhong, S. (2007) Antimicrobial susceptibility and molecular detection of chloramphenicol and florfenicol resistance among Escherichia coli isolates from diseased chickens. J. Vet. Sci., 8(3): 243-247.

41. Dai, L., Lu, L.M., Wu, C.M., Li, B.B., Huang, S.Y., Wang, S.C., Qi, Y.H. and Shen, J.Z. (2008) Characterization of antimicrobial resistance among Escherichia coli isolates from chickens in China between 2001 and 2006. FEMS Microbiol. Lett., 286: 178-183.

42. Ozawa, M., Harada, K., Kojima, A., Asi, T. and Sameshima, T. (2008) Antimicrobial susceptibilities, serogroups, and molecular characterization of avian pathogenic Escherichia coli isolates in Japan. Avian Dis., 52: 392-397.

43. Zanatta, G.F., Kanashiro, A.M.I., Castro, A.G.M., Cardoso, A.L.S.P., Tessari, E.N.C. and Pulic, S.C.P. (2004) Susceptibility of Escherichia coli strains of avian origin to antimicrobials. Arquivo Inst. Biol., 71(3): 283-286.

44. Ying, H.J., Chen, S.J., Chang, H., Dong, L., Yang, M. and Kamagata, Y. (2008) Phenotyping and genotyping of antibiotic-resistant Escherichia coli isolated from a natural river basin. Environ. Sci. Technol., 42(9): 3415-3420.

45. Xiu, M.W., Xiao, P.L., Wan, J.Z., Hong, X.J., Jian, S., Mei, J.Z., Xue, F.H., Dong, X.L. and YaHong, L. (2010) Prevalence of serogroups, virulence genotypes, antimicrobial resistance, and phylogenetic background of avian pathogenic Escherichia coli in south of China. Foodborne Pathog. Dis., 7(9): 1099-1106.

46. Magiorakos, A.P., Srinivasan, A., Carey, R.B., Carmeli, Y., Falagas, M.E., Giske, C.G., Harbarth, S., Hindler, J.F., Kahlmeter, G., Olsson-Liljequist, B., Paterson, D.L., Rice, L.B., Stelling, J., Struelens, M.J., Vatopoulos, A., Weber, J.T. and Monnet, D.L. (2012) Multidrug-resistant, extensively drug-resistant and pandrug-resistant bacteria: an international expert proposal for interim standard definitions for acquired resistance. Clin. Microbiol. Infect., 18: 268-281.

47. Szmolka, A., Anjum, M.F., Ragione, R.M., Kaszanyitzky, E.J. and Nagy, B. (2012) Microarraybased comparative genotyping of gentamicin-resistant Escherichia coli strains from food animals and humans. Vet.
Microbiol., 156(1/2): 110-118.

48. Zhao, J.Y. and Dang, H. (2012) Coastal seawater bacteria harbor a large reservoir of plasmid-mediated quinolone resistance determinants in Jiaozhou Bay, China. Microb. Ecol., 64, 187-199.

49. Alm, E.W., Zimbler, D., Callahan, E. and Plomaritis, E. (2014). Patterns and persistence of antibiotic resistance in faecal indicator bacteria from freshwater recreational beaches. J. Appl. Microbiol., 117: 273-285.

50. Henriques, I.S.1., Fonseca, F., Alves, A., Saavedra, M.J. and Correia, A. (2008) Tetracycline-resistance genes in gram-negative isolates from estuarine waters. Lett. Appl. Microbiol., 47(6): 526-533.

51. Scaria, J., Warnick, D.L., Kaneene, B.J., May, K., Teng, C.H. and Chang, Y.F. (2010) Comparison of phenotypic and genotypic antimicrobial profiles in Escherichia coli and Salmonella enterica from the same dairy cattle farms. Mol. Cell Probes, 24(6): 325-345.

52. Suzuki, S., Horinouchi, T. and Furusawaa, C. (2014) Prediction of antibiotic resistance by gene expression profiles. Nat. Commun., 5: 5792.

53. Lewin, B. (1997) Genes. Oxford University Press, New York

54. Petrova, M., Gorlenko, Z. and Mindlin, S. (2009) Molecular structure and translocation of a multiple antibiotic resistance region of a Psychrobacter psychrophilus permafrost strain. FEMS Microbiol. Lett., 296: 190-197.

55. Sundin, G.W. (2000) Examination of base pair variants of the strA-strB streptomycin resistance genes from bacterial pathogens of humans, animals and plants. J. Antimicrob. Chemother., 46: 848-849.

56. Daniels, J.B., Call, D.R. and Besser, T.E. (2007) Molecular epidemiology of blaCMY-2 plasmids carried by Salmonella enterica and Escherichia coli isolates from cattle in the Pacific Northwest. Appl. Environ. Microbiol., 73: 8005-8011.

57. Mulvey, M.R., Susky, E., McCracken, M., Morck, D.W. and Read, R.R. (2009) Similar cefoxitin-resistance plasmids circulating in Escherichia coli from human and animal sources. Vet. Microbiol., 134: 279-287.

58. Escudero, E., Vinue, L., Teshager, T., Torres, C. and Moreno, M.A. (2010) Resistance mechanisms and farmlevel distribution of fecal Escherichia coli isolates resistant to extended-spectrum cephalosporins in pigs in Spain. Res. Vet. Sci., 88: 83-87.

59. Zdolec, N., Racic, I., Vujnovic, A., Zdelar-Tuk, M., Matanovic, K., Filipovic, I. and Spicic, S. (2013) Antimicrobial resistance of coagulase-negative staphylococci isolated from spontaneously fermented sausages. Food Tech. Biotech., 51(2): 240.

60. Osman, K., Badr, J., Al-Maary, K.S., Moussa, I.M., Hessain, A.M., Girah, Z.M.A., and Saad, A. (2016) Prevalence of the antibiotic resistance genes in coagulase-positive-and negative-Staphylococcus in chicken meat retailed to consumers. Front. Microbial., 7: 1846. 